\title{
Chapter 17 \\ Ecosystem Restoration Using the Near-Natural Method in Shanghai
}

\author{
Liang Jun Da and Xue Yan Guo
}

\begin{abstract}
Recently, there has been a growing trend toward developing eco-cities that are rationally structured, function efficiently, and maintain a harmonious relationship with the environment. Functional eco-cities demonstrating symbiosis with nature are not merely a current urban development goal, but also make an important contribution to the establishment of sustainable development strategies across the world. The "near-natural" method of ecological construction and restoration has attracted attention worldwide, and has been widely proven to be an effective method of constructing ecological cities in practice. It will also play a key role in urban landscaping and greening in China. After studying the problems associated with constructing an ecocity in Shanghai, we proposed the use of the near-natural method to construct an urban ecosystem in the city and introduced a theory and methodology for creation of "near-natural forests" and "near-natural water systems." All the cases we studied demonstrated that restoration using the near-natural method could be more effective, long lasting, and economical than existing methods, and that the method is now worthy of promotion as a means of constructing environments for human settlement.
\end{abstract}

Keywords Near-natural • Ecological restoration • Urban greening • Native species

\author{
L.J. Da $(\bowtie)$ \\ Department of Environmental Science, East China Normal University, \\ 500 Dongchuan Rd., Shanghai 200241, China
}

Shanghai Key Lab for Urban Ecological Processes and Eco-Restoration, East China Normal University, 500 Dongchuan Rd., Shanghai 200241, China

Tiantong National Station of Forest Ecosystem, East China Normal University, Normal University, Ningbo, Zhejiang, Shanghai 315114, China e-mail: 1jda@des.ecnu.edu.cn

X.Y. Guo

Department of Environmental Science, East China Normal University, 500 Dongchuan Rd., Shanghai 200241, China

e-mail: xueer308@sina.com 


\subsection{Introduction}

The city, a typical artificial system constructed according to the will of humans, is an ecosystem composed of social, economic, and natural sub-ecosystems. The natural sub-ecosystem suffers drastic damage as a result of long-term human activities and rapid urbanization. The latter in particular causes many ecological problems, such as loss of native species and invasion of alien species, due to environmental pollution (Cao et al. 2008; Kan et al. 2004; Ren et al. 2003; Wang et al. 2008; Zhang et al. 2010) and local climate change (Xu et al. 2008; Zhang et al. 2009). This has a significant impact on the city's survival and development.

As a large metropolis characterized by a high-density population, concentrated industries, and resource shortages, Shanghai has also experienced such problems. Consequently, its leaders now realize the importance of healthy ecosystems to the city's process of development into an eco-city in the new century. In recent years, Shanghai has made great progress in restoring the natural sub-ecosystem, but some problems still remain due to the desire to achieve its aims quickly using simple methods to shorten the restoration process.

One example is employing monoculture plantations-usually consisting of conifers or other rapidly growing pioneer trees - to restore degraded terrestrial landscape. Monoculture plantations are, however, quite vulnerable to plant diseases and insect pests (Gibson and Jones 1977; Ciesla and Donaubauer 1994; Gadgil and Bain 1999) due to their extreme homogeneity. Moreover, high-density planting of these monotypic stands limits the resources available, inducing intense competition and low seedling and sapling recruitment rates. As a consequence, these forests always exhibit simple vertical structure and are unstable, in addition to harboring a lower animal diversity (Kloor 2000).

A second example is using a large proportion of non-native species in urban greening for decorative and aesthetic reasons, while natural vegetation comprising native species suitable for local habitats is rarely used. Most non-native species are not well suited to their location, which results in low survival rates and high management costs. As a result, the sustainability of greening dominated by non-native species is low and its ecological function weak.

Third, water area-which has shrunk greatly during recent decades-is often increased using water systems devoid of plant or animal life, or waterscapes with concrete bottoms and revetments. Curved stream channels are also straightened to prevent or discharge floods, and concrete revetments have replaced the natural littoral zone. As a result, all such water areas have lost the connection between water and soil and cannot provide habitats for living beings, resulting in weak selfpurification capacity and accumulation of nutrients in the water. Algae bloom occurs frequently without intact aquatic ecosystems and hierarchical trophic webs (Kondolf 1995), especially as a result of losing submerged vegetation and herbivores.

Hence, if the negative consequences of the above three methods are to be avoided, it is important to comply with ecological principles to restore the structure and function of the degraded urban natural sub-ecosystem, both terrestrial and aquatic 
(Hobbs 1996; Allen et al. 1997; Palmer et al. 1997). This remains a pressing goal for urban areas (Kloor 2000). Based on experience gained by many researchers over several decades (Miyawaki 1998; Wang et al. 2002), we used a method emulating natural processes-specifically the "near-natural" method as described below-to restore the degraded natural sub-ecosystem in Shanghai.

\subsection{Theoretical Basis for Near-Natural Restoration}

\subsubsection{The Near-Natural Method of Afforestation}

The near-natural method is based on the concepts of potential natural vegetation and succession theory in vegetation ecology (Miyawaki 1998; Wang et al. 2002). In natural forest ecosystems, the succession from the establishment of pioneer plant communities to forested climax communities can take hundreds of years. However, the near-natural approach, using seedlings of native woody species raised in plastic pots to revegetate reformed soil, can accelerate succession and create a near-climax community in a shorter time period and at low cost. This near-climax community would have a complex structure with high species diversity, multilayer canopies, and high biomass in a stable state, requiring less management.

\subsubsection{The Near-Natural Method of River Construction}

In 1938, Seifert raised the concept of near-natural river construction (Seifert 1938). In the last two decades, the popularity of ecological concepts in Japan has led to the construction of attractive waterside spaces, recovery and creation of living rivers, and improvements in river environments and ecosystems (Zhu et al. 2006). Compared with traditional projects, the prominent characteristic of near-natural construction is that biological diversity, density, and productivity increase several times over (Gao 1999).

\subsection{Near-Natural Forest Creation}

A 3,000 $\mathrm{m}^{2}$ near-natural forest was established in the Pudong New Area of Shanghai $\left(31^{\circ} 13^{\prime} \mathrm{N}, 121^{\circ} 32^{\prime} \mathrm{E}\right)$ in June 2000 . The climate of this region is subtropical monsoon with a mean annual temperature of $18.1^{\circ} \mathrm{C}$ and precipitation of $1,158 \mathrm{~mm}$. The potential natural vegetation local to Shanghai is dominated by evergreen broadleaved forest like Cyclobalanopsis glauca, C. myrsinaefolia, Castanopsis sclerophylla, and Machilus thunbergii. Due to the high water table and high soil salinity 
Table 17.1 Species list of planted seedlings for a near-natural forest in Pudong, Shanghai, in 2000. All species are native to the local region, where evergreen broad-leaved forest is considered to be the zonal vegetation

\begin{tabular}{llc}
\hline Plant species & Life form & Density $\left(\mathrm{per} 3,000 \mathrm{~m}^{2}\right)$ \\
\hline Cyclobalanopsis myrsinaefolia & Evergreen tree & 2,500 \\
Cyclobalanopsis glauca & Evergreen tree & 2,500 \\
Castanopsis sclerophylla & Evergreen tree & 2,500 \\
Machilus thunbergii & Evergreen shrub & 2,830 \\
Ligustrum lucidum & Evergreen shrub & 370 \\
Distylium racemosum & Evergreen shrub & 150 \\
Pittosporum tobira & Evergreen shrub & 400 \\
Fatsia japonica & Evergreen shrub & 300 \\
Aucuba chinensis var.variegata & Evergreen shrub & 300 \\
Liquidambar formosana & Deciduous tree & 300 \\
Swida alba & Deciduous shrub & 200 \\
Total & & 12,350 \\
\hline
\end{tabular}

in Shanghai, flat ground was reformed into a landscape with micro-topographies to create suitable habitats for climax woody species before transplanting seedlings.

All species of seedling used in the afforestation were native to Shanghai and surrounding areas (Table 17.1). Seedlings were raised in greenhouses until they developed a strong root system and reached a height of 0.2 to $0.8 \mathrm{~m}$. They were planted at densities as high as three to five individuals per $\mathrm{m}^{2}$, because high-density planting favors natural selection of the best seedlings that match their microsite conditions, at the same time providing a source of additional seedlings to meet greening needs in the future. After planting, the bare ground was covered with rice straw and weeding was undertaken every 2 or 3 years. After 5 years, no further management was necessary.

\subsubsection{Monitoring: Stand Dynamics and Eco-Benefits}

Two adjacent plots, each of $200 \mathrm{~m}^{2}$, were set up. In each plot, the height and diameter at breast height for each individual taller than $1.5 \mathrm{~m}$ were measured in 2001, 2003, 2004, 2006, and 2010.

To assess the ecological benefits of the near-natural forest, the forest was compared with an evergreen broad-leaved forest in Ningbo, near Shanghai, and other artificial forests in Shanghai (Table 17.2), based on measurements of negative air ions (NAI), air temperature and humidity, air microorganisms, and soil microorganisms in 2007.

NAI, and air temperature and humidity, were measured in the center of each plot at a height of $1.5 \mathrm{~m}$ above ground every $2 \mathrm{~h}$ between 9:00 and 17:00 over three consecutive days in May. Measurements were recorded for $10 \mathrm{~min}$ at a time using an NAI monitor (ITC-201A), which can measure second-by-second and automatically save sets of data. 


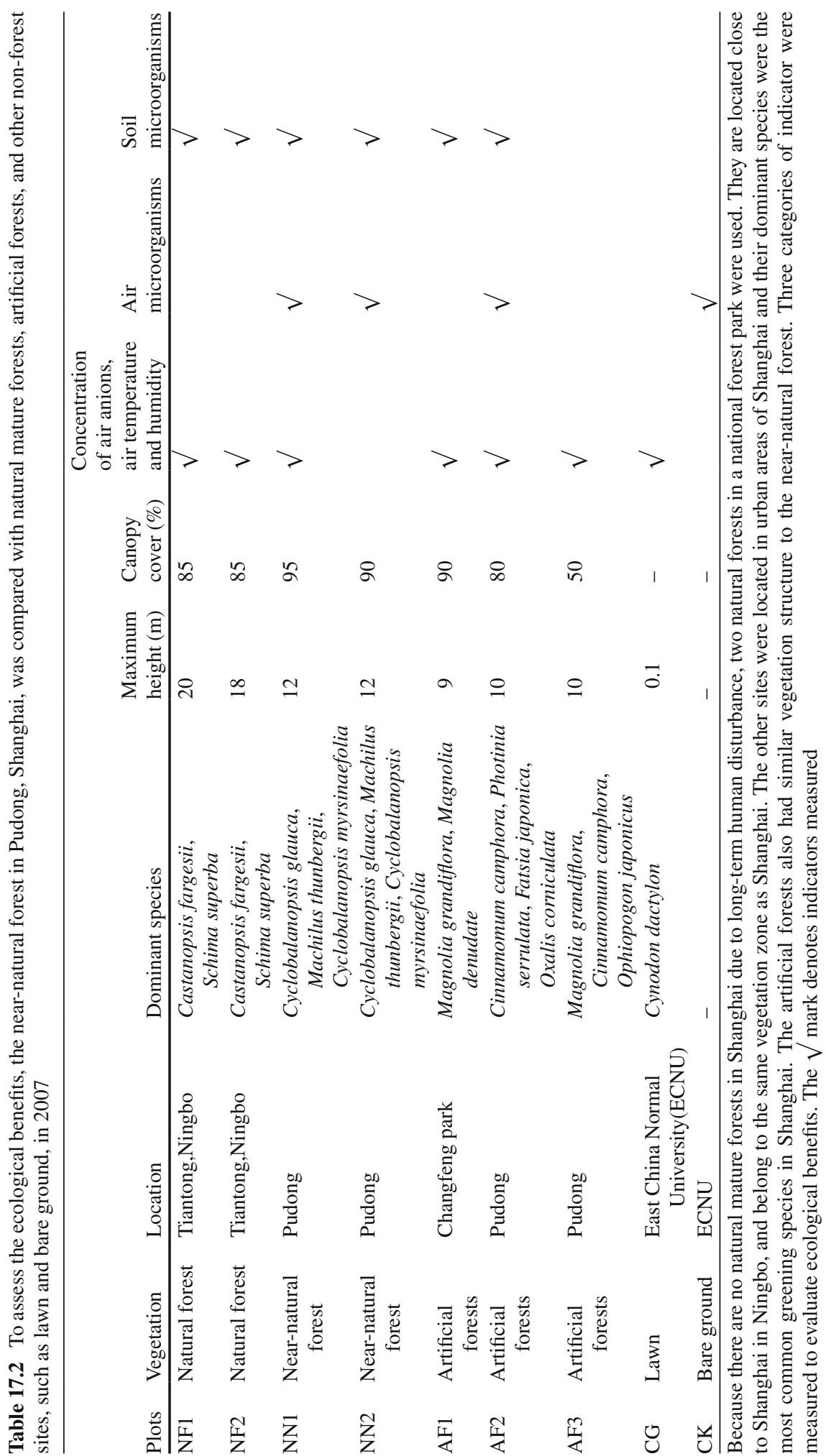


Air microorganisms were collected using an air microorganism sampler (FA-1) at a height of $1.5 \mathrm{~m}$ above ground for $10 \mathrm{~min}$, with three replications in each plot in spring, summer, fall, and winter, respectively. The culture media for air bacteria, air fungi, and air actinomycetes were the nutrient agar, Rose Red sodium agar, and Gause No.1, respectively. After sampling, the media were taken back to the laboratory to culture and count.

Soil microorganisms were cultured by means of the spread plate method using similar media to those used for air microorganisms. The soil samples were obtained from each plot in May at five points distributed in a " $Z$ " shape at $0-10 \mathrm{~cm}$ and 10-20 cm depths. These samples were mixed using the multi-point soil samples method, taken back to the laboratory and diluted for determination.

\subsubsection{Monitoring Results}

\subsubsection{Plant Species Composition and Dynamics}

The seedling survival rate the first winter was greater than $90 \%$. From 2001 to 2010, the species composition remained fairly stable, with the exception of the invasion of several native non-planted species (Table 17.3).

Until 2010, the tenth year after transplanting, the average heights of Liquidambar formosana and Ligustrum lucidum were $9.2 \mathrm{~m}$ and $6.5 \mathrm{~m}$, respectively (Fig. 17.1). The average heights of Machilus thunbergii, Cyclobalanopsis glauca, and Distylium racemosum were lower in 2010 than in 2006, because of the death of several larger individuals and the recruitment of considerable numbers of seedlings. In addition, native deciduous species, including Ulmus parvifolia, Sapium sebiferum, Salix matsudana, Broussonetia papyrifera, Cinnamomum camphora, and Podocarpus macrophyllus, invaded the stand, via seed dispersal by wind and by birds. In 2010, the largest individual was Sapium sebiferum, at $12.5 \mathrm{~m}$ in height, while Broussonetia papyrifera, the early invader, had reached a height of $9.5 \mathrm{~m}$.

Ligustrum lucidum and Liquidambar formosana always topped the list of average breast-height basal areas from 2003 onwards (Table 17.3). In addition, it is notable that the breast-height basal areas of Cyclobalanopsis myrsinaefolia and Cyclobalanopsis glauca were smaller in 2004 than in 2003. Similarly, those of the Machilus thunbergii and Ligustrum quihoui were smaller in 2010 than in 2006, as a result of the growth of considerable numbers of new seedlings into the shrub layer and the death of several larger individuals.

\subsubsection{Ecological Benefits}

The concentrations of NAI in the near-natural forest were much higher than in artificial forests in urban areas, but much lower than in true natural forests. This is because high tree density and a multi-layer vertical structure can effectively increase 


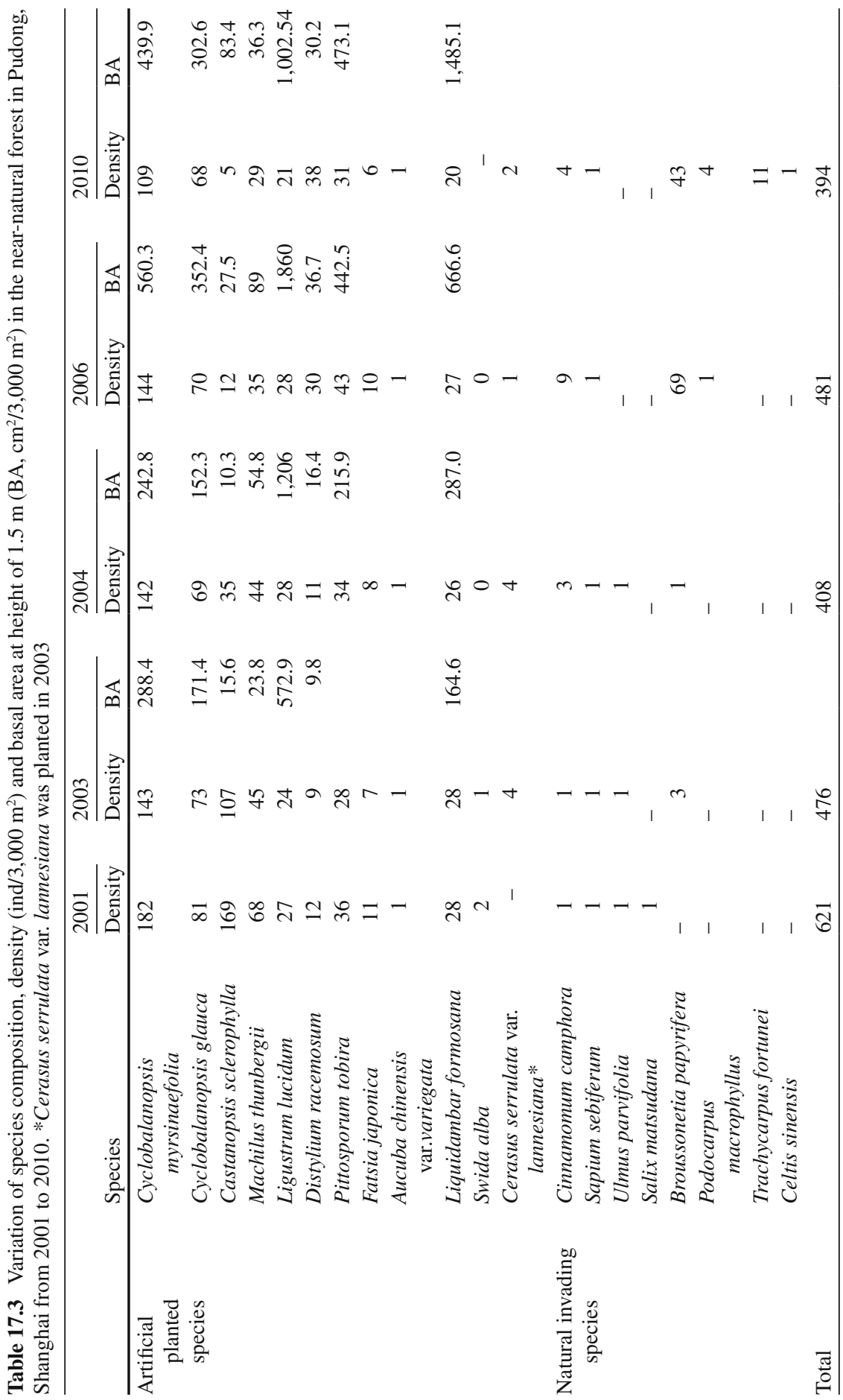




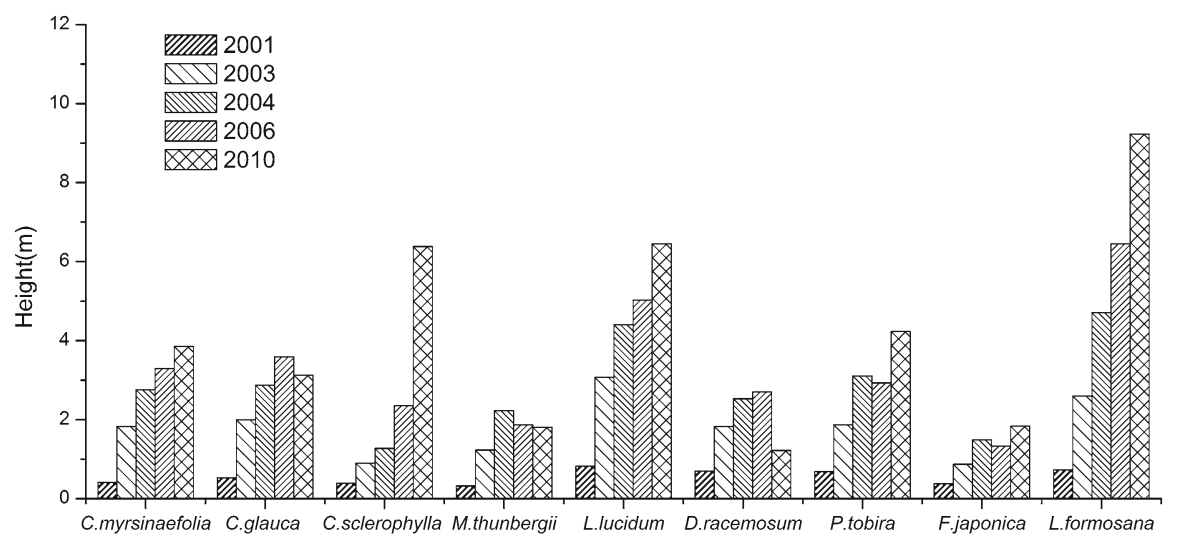

Fig. 17.1 Dynamics of the main species in terms of average height

the concentration of NAI (Shao and He 2000). Air temperature and humidity, meanwhile, demonstrated no significant difference between the near-natural forest and artificial forests in urban areas. The average air bacteria concentration of the near-natural forest was lower than the Pudong and East China Normal University sample plots, but air fungi and actinomycetes were higher. The near-natural forest's air bacteria concentration was also lower than that of artificial forests, while air fungi and actinomycetes were again higher. Within the soil, meanwhile, the abundance of microorganisms in the near-natural forest was greater than in artificial forests, and close to the abundance in true natural forests, due to thicker litter in near-natural forest which can increase soil microorganisms to improve soil fertility (Table 17.4) (Alexander 1983; Huang and Wu 2002).

In this area, a near-natural forest had developed within 10 years. Since both canopy and subcanopy species were planted, the forest exhibited a vertical structure consisting of layers of trees, shrubs, and herbaceous plants. This vertical structure fosters greater species diversity by providing more niches for organisms. The area has now grown into beautiful woodland with remarkable effects on the landscape, and has provided considerable ecological benefits (Fig. 17.2).

\subsubsection{Assessment of Near-Natural Forest Experiment and Proposal for Improvement}

Because the near-natural forest experiment used native species and involved little management, the costs were limited considerably. The forest ultimately consists of both the planted native species and those species that invaded naturally. Diversification of species has therefore continued without any additional cost. The variety of species will enhance resistance to pests, diseases, and other disturbances. 


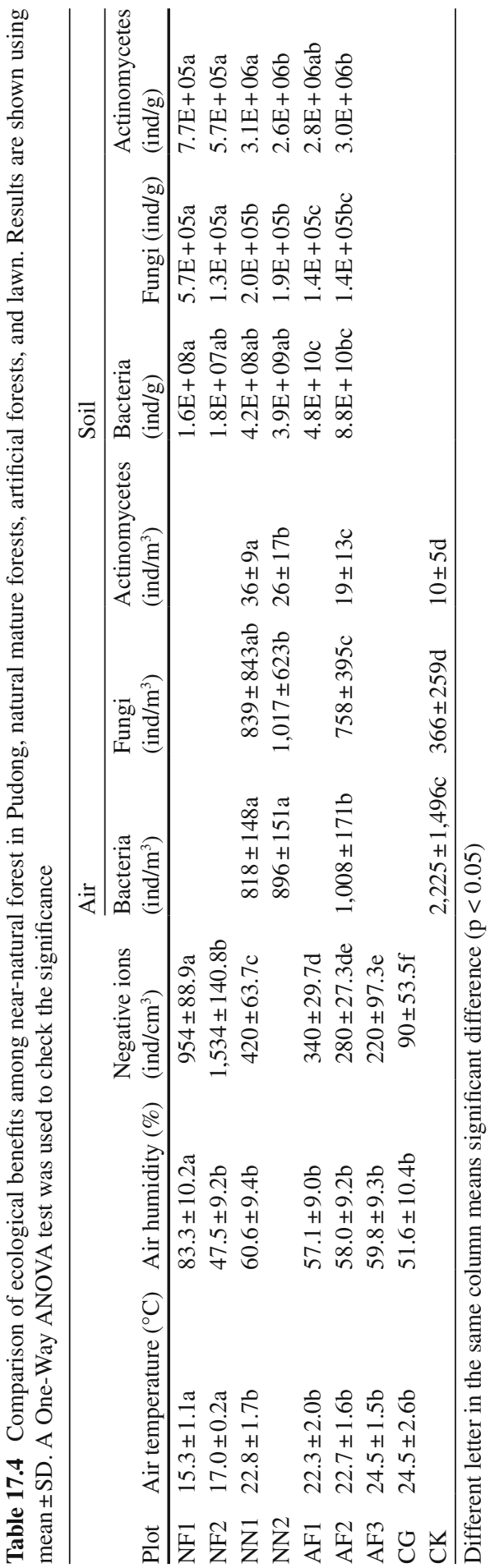



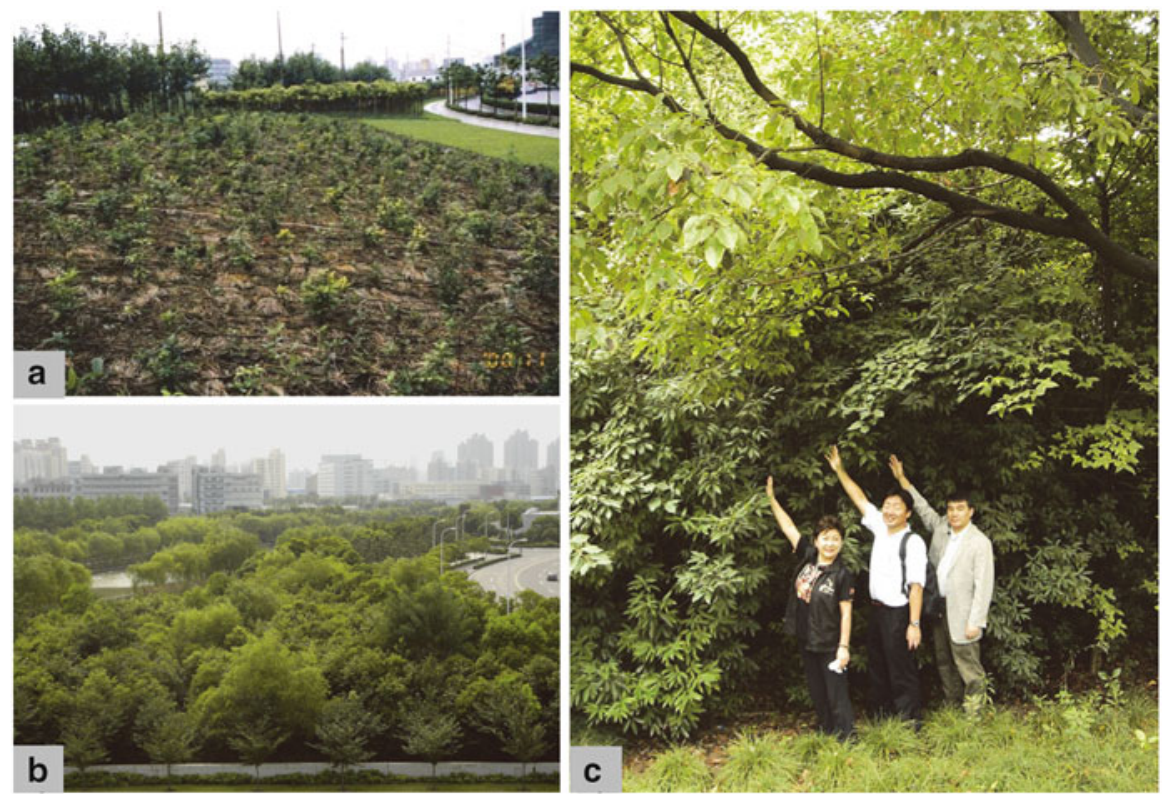

Fig. 17.2 (a) Initial planting (June 11, 2000); (b) Same site, four years later (June 8, 2004); (c) Seven years later (July 4, 2007)

Moreover, near-natural forests require much less maintenance than other forms of urban greening, particularly in the later stages of growth.

Due to its structure and the nature of its ecological benefits, the near-natural forest formed a stable community after 10 years of development. It also provided ecological benefits on a greater scale than traditional artificial forests, rendering it much more similar to natural forests. In addition, many birds and insects were recorded in the near-natural forest, indicating a potential role as a refuge for animals in urban settings. We consider that further increases in ecological benefits are likely to occur as the near-natural forest grows, and foliage increases.

But one notable problem during this experiment was the high mortality rate among several climax evergreen broad-leaved species in the first few years. These were species intended as the dominant component of the near-natural forest at the mature stage. Investigation revealed that the mortality rate was related to the lack of shade to protect seedlings against overexposure to strong sunlight. This conclusion was supported by the fact that Cyclobalanopsis myrsinaefolia and Cyclobalanopsis glauca demonstrated higher survival rates in 2004 due to the shade provided by fastgrowing Ligustrum lucidum and Liquidambar formosana.

To further optimize the method for near-natural forest creation in Shanghai, we planted another two near-natural forests during the winter of 2003 in the city's Minghang district. The seedlings of the target climax community demonstrated a higher growth rate with lower mortality than in the original experiment. In this case, the deciduous trees grew faster than the evergreen ones, and the resulting closed 
canopy shielded the evergreen target seedlings from overexposure. To optimize the traditional Miyawaki Method (Miyawaki 1998; Miyawaki 1999), therefore, we proposed a planting method based on multilayer deciduous-evergreen mixed forests comprising trees of different ages. The key to the new method is to create a mixed deciduous-evergreen community by simultaneously planting shade-tolerant evergreen broad-leaved species and light-demanding deciduous broad-leaved species, but using smaller individuals for the former and bigger individuals for the latter to form a multilayer vegetation structure. The shade-tolerant evergreen species benefit from the rapid growth of the light-demanding deciduous species, which offer shade and nutrients in the form of litter layer-based fertilizer, improving the soil for the evergreen species.

\subsection{Near-Natural River Construction}

Degradation of aquatic ecosystems caused by eutrophication is a common problem in China's rivers and lakes in recent years. Liwa River passes through the campus of East China Normal University, Shanghai (Fig. 17.3), and its water quality was previously so poor that it failed to qualify for Class V (the least stringent category) under China's National Surface Water Environmental Quality Standard (GB3838-2002). Its nitrogen and phosphorus concentrations were two to four times higher than the required standard. Comprehensive treatment of Liwa River was initiated in August 2004. By the end of 2005, rehabilitation was complete, including

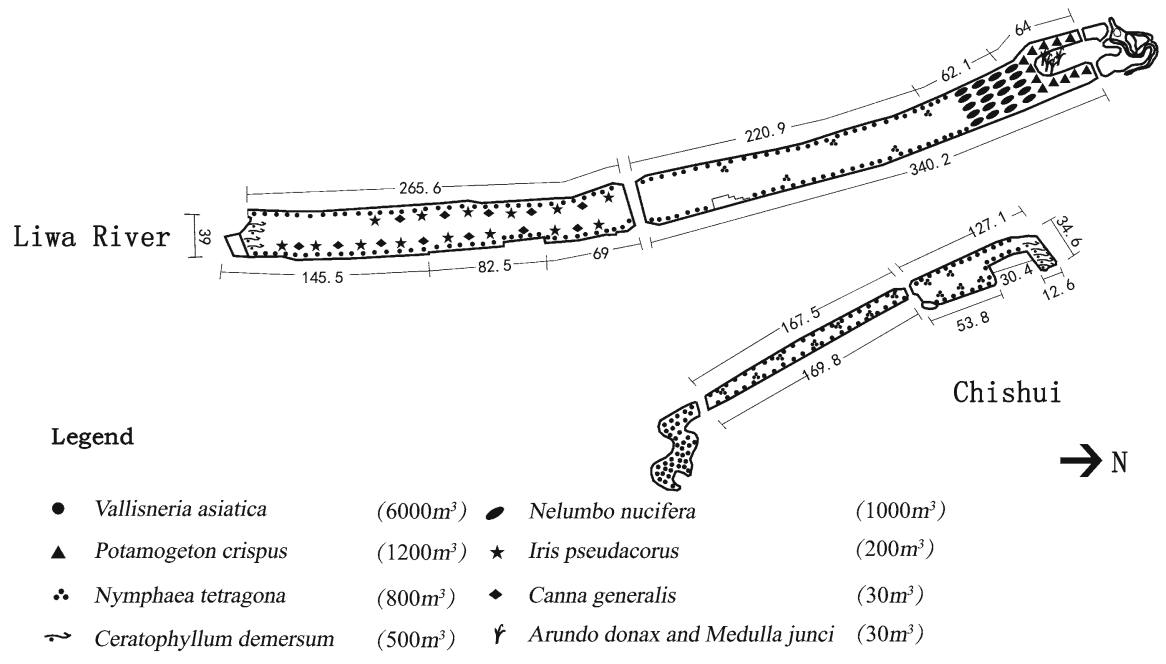

Fig. 17.3 Aquatic plant growing sites in Liwa River (Unit: m) 
reducing pollutant input, dredging, improving water cycling, and setting up a membrane bioreactor. Near-natural restoration work to establish an aquatic ecosystem with an integrated trophic web started in April 2006, and ended in November the same year. The ecosystem was created using three ecological engineering systems based on sediment dredging and prevention of pollution.

\section{Engineering of Water Quality Control}

Methods of river-base solidification and biology were used to increase water transparency and ameliorate water quality. Fountains were used to increase the concentration of dissolved oxygen and change the grade distribution, which can enhance capacity for decomposition of organic material and remove excess nutrients from water.

2. Engineering of Water Landscape Construction

To naturalize the concrete banks along Liwa River without any destruction, plant species with trailing branches, such as Jasminum mesnyi and Hedera nepalensis var. sinensis, were used to cover the banks, while emerging plants on fiber drums floating on the water near the shoreline alleviate erosion and enhance the sense of a visual landscape.

Since aquatic vegetation is highly effective in removing pollutants, from April to June 2006 macrophyte communities dominated by native species were reestablished to increase the area of aquatic vegetation and biomass in the river. The aquatic vegetation comprised submerged plants, emerging plants, and floating plants, to form a three-layer vertical community structure. Hydrophyte, helophyte, hygrophyte, and mesophyte species were selected for reestablishment, some of which offered efficient nutrient removal or allelopathic effects on algae (Li et al. 2006; Chen et al. 2009). In addition, floating islands made of fiber mats were set up in areas where the depth was beyond the recruit limit of aquatic vegetation, and floating-leaved plants such as Nymphaea tetragona and emerging plants were planted on the mats.

3. Construction of Food Web in Water and Engineering of Biological Diversity After aquatic vegetation was established, planktivores (Hypophthalmichthys molitrix and Aristichthys novilis) and an invertebrate (Bellamya quadrata) were introduced to the river in November 2006. B. quadrata was introduced at between 0.5 and $1.0 \mathrm{~kg} / \mathrm{m}^{3}$, with adult individuals dominating. H. molitrix and $A$. novilis were introduced at $0.5-0.6 \mathrm{~kg} / \mathrm{m}^{3}$ (about 2.0 fish per $\mathrm{m}^{3}$ ) and $0.05-0.06 \mathrm{~kg} / \mathrm{m}^{3}$ (about 0.2 fish per $\mathrm{m}^{3}$ ), respectively, with young individuals dominating. These species are not only part of the local food web, but are also powerful inhibitors of algal bloom (Starling and Rocha 1990).

Subsequently, Carassius auratus, Parabramis pekinensis and other native waterfowl at higher trophic levels were added into the river to form an ecosystem with a long web chain including producer, herbivore, predator, and decomposer. Eventually, indirect export of organic matter and nutrients from the water could be achieved by fishing, capturing aquatic animals, and harvesting plants. 


\subsubsection{Monitoring: Water Quality and Biocoenosis}

\subsubsection{Water Quality}

Eight water samples were obtained $0.5 \mathrm{~m}$ underwater and determined according to the National Surface Water Environmental Quality Standard (GB3838-2002). The parameters were measured as follows: total phosphorus (TP) using the ammonium molybdate spectrophotometric method; total nitrogen (TN) via the alkaline potassium persulfate digestion-UV spectrophotometric method; chemical oxygen demand (COD) by the dichromate method; dissolved oxygen (DO) using the iodimetric method; Chlorophyll-a via spectrophotometry; and water transparency by Secchi disc.

\subsubsection{Aquatic Plants}

The fresh weight was measured with three replications by harvesting all plants in a square of $1 \mathrm{~m}^{2}$ in each season. After that, fresh samples were air-dried, smashed and sieved for later determination. Total phosphorus and total nitrogen were measured using the perchloric acid-sulfuric acid solution method.

\subsubsection{Aquatic Animals}

Samples of zoobenthos were collected by $1 / 16 \mathrm{~m}^{2}$ Peterson grab at three points. Samples of fish were obtained by fishing in a certain location. The fresh weight was measured after washing and identification.

\subsubsection{Monitoring Results}

\subsubsection{Variation of Water Quality}

In general, water quality was improved from below Class V to Class II based on the National Surface Water Environmental Quality Standard (GB3838-2002) (Table 17.5). TN, TP, COD, and Chlorophyll-a were greatly decreased. From 2003 to 2007 , the transparency increased from $20-40$ to $80-100 \mathrm{~cm}$. The DO was low with an average value less than $5 \mathrm{mg} / \mathrm{L}$ and a minimum of $0.8 \mathrm{mg} / \mathrm{L}$ in summer 2003, increasing to $9.09-11.18 \mathrm{mg} / \mathrm{L}$ in November 2007. The concentration of Chlorophyll-a decreased from an average level of $19.41 \mu \mathrm{g} / \mathrm{L}$ to around $7.86 \mu \mathrm{g} / \mathrm{L}$. Algae was remarkably inhibited after introducing $H$. molitrix and A. novilis. In addition, inhibition of algal growth via competition from aquatic plants was immeasurable (Chen et al. 2009). 
Table 17.5 Water quality of Liwa River

\begin{tabular}{llllll}
\hline Date & Engineering phase & $\begin{array}{l}\text { TN } \\
(\mathrm{mg} / \mathrm{L})\end{array}$ & $\begin{array}{l}\mathrm{TP} \\
(\mathrm{mg} / \mathrm{L})\end{array}$ & $\begin{array}{l}\mathrm{COD} \\
(\mathrm{mg} / \mathrm{L})\end{array}$ & Chlorophyll-a $(\mu \mathrm{g} / \mathrm{L})$ \\
\hline 2003.10 & Before treatment & 11.34 & 1.13 & 58.9 & 123.52 \\
2005.11 & $\begin{array}{c}\text { Traditional treatment } \\
\text { completed }\end{array}$ & 1.85 & 0.23 & 33.3 & - \\
$\quad \begin{array}{c}\text { Near-natural restoration } \\
\text { completed }\end{array}$ & 0.89 & 0.19 & 20.2 & 19.41 \\
2006.11 & 0.41 & 0.03 & 21.5 & 7.86 \\
\hline
\end{tabular}

\subsubsection{Biocoenotic Dynamics}

The distribution and biomass of each introduced species was recorded monthly for 2 years after restoration (Table 17.6). In comparison with their areas in 2006, the ranges of $P$. crispus, $N$. nucifera, and Ceratophyllum demersum expanded $96 \%$, $100 \%$, and $84 \%$, respectively. In contrast, Vallisneria asiatica and Iris tectorum lost $72 \%$ and $50 \%$ of their ranges, respectively. Range shrinkage of V. asiatica was observed only in deep-water areas, which suggests that the decrease in V. asiatica was mainly due to insufficient light ( $\mathrm{Li}$ et al. 2008).

Most aquatic species, such as $V$. asiatica and $C$. demersum, attained maximum biomass in summer and fall, except for $P$. crispus. Therefore, $P$. crispus played an important role in removing nutrients, filtering particles, and replenishing oxygen in winter when the other species lost vitality. As a result, the aquatic vegetation had an observable effect on the removal of excess nutrients throughout the whole year and provided habitats and sufficient food for fish even in the winter.

Most aquatic plants reached the highest fix rate of nitrogen and phosphorus in fall, but $P$. crispus and $N$. nucifera were the highest in spring and in summer respectively. Calculations based on data collected showed that $12.8 \mathrm{~kg}$ of N and $1.6 \mathrm{~kg}$ of $\mathrm{P}$ could be removed from the water by harvesting P. crispus in May and N. nucifera in November every year (Table 17.7). The effect would be even better if $N$. nucifera was harvested in summer. The data indicated that harvesting aquatic vegetation was an effective treatment for urban river eutrophication (Graneli and Solander 1988; Meuleman et al. 2004).

Two years after the restoration, native zoobenthos species Radix swinhoei and Planorbidae spp, and native fish Saurogobio dumerili were found in addition to the species artificially introduced. Invertebrates in particular were thriving in the flourishing macrophyte communities. The number of $B$. quadrata, $R$. swinhoei and Planorbidae spp increased to $82.5,151.5$, and $19.3 \mathrm{~m}^{3}$, respectively. These increases showed that food chains had reestablished with increased species richness in the restored river. 


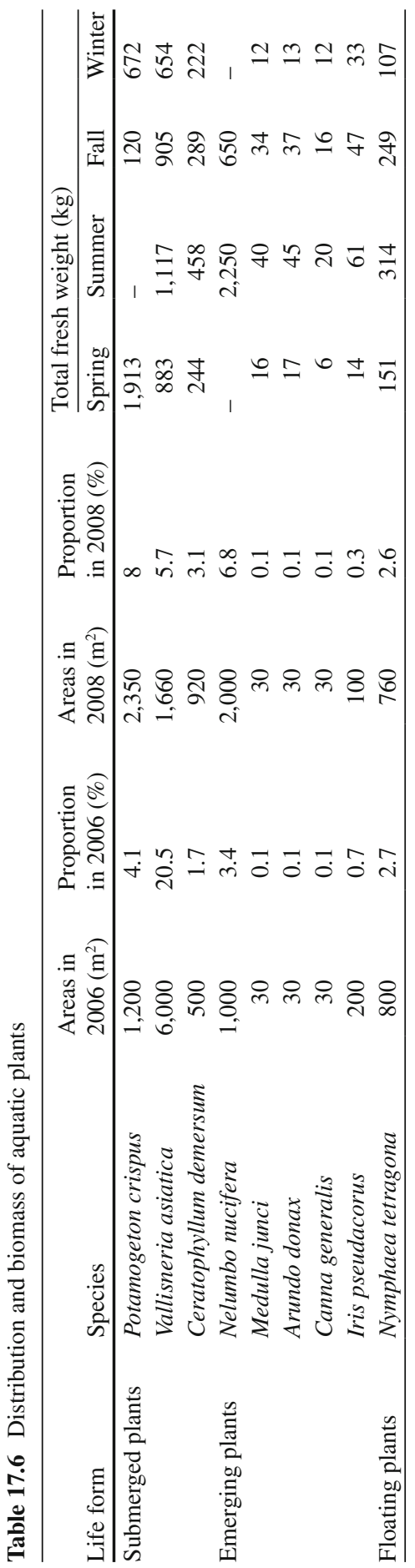




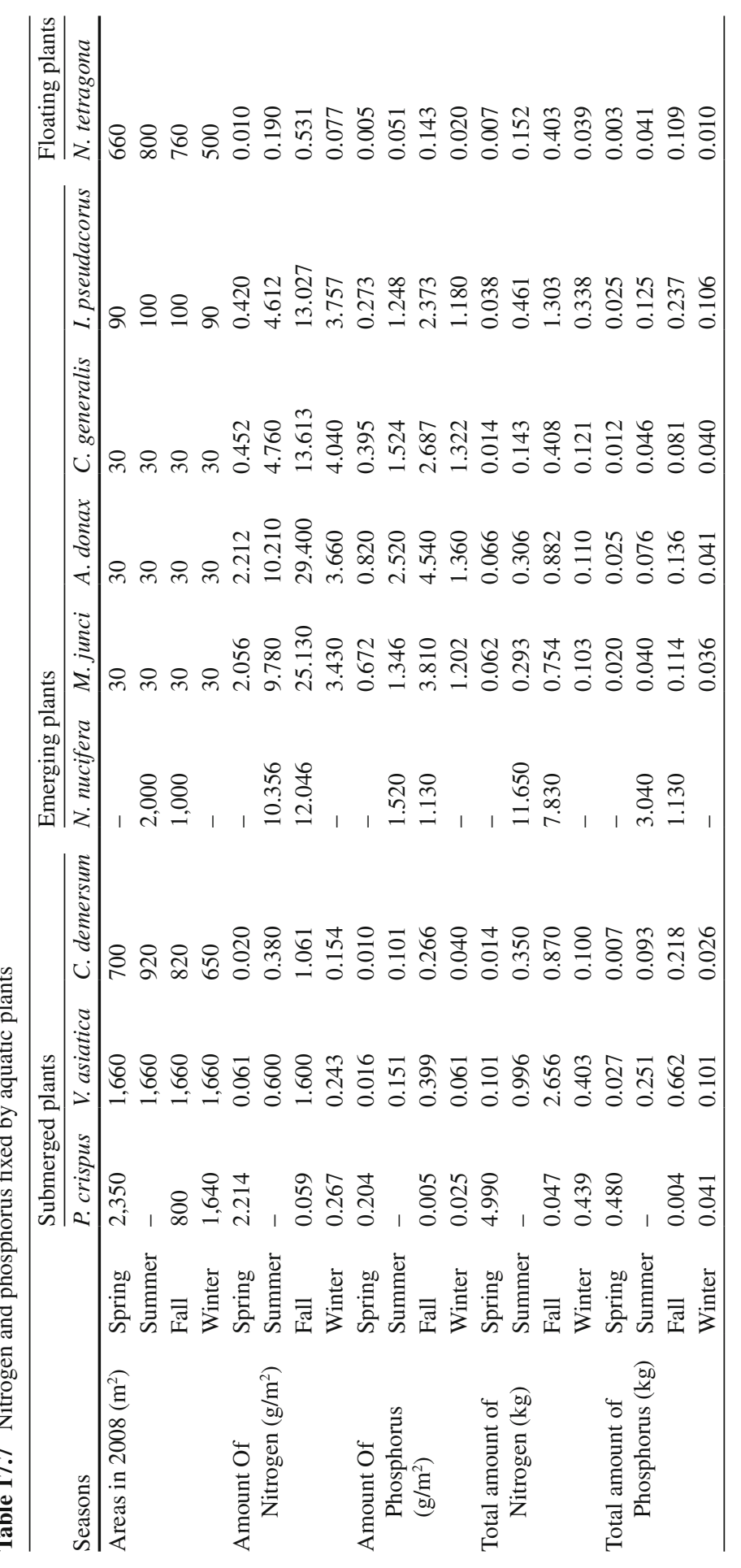


Table 17.8 Comparison of expenses for removing nitrogen and phosphorus between traditional treatment and near-natural restoration engineering

\begin{tabular}{clllll}
\hline & $\begin{array}{l}\text { Total amount } \\
\text { of } \mathrm{N}(\mathrm{kg}) \\
\text { removed }\end{array}$ & $\begin{array}{l}\text { Total amount } \\
\text { of } \mathrm{P}(\mathrm{kg}) \\
\text { removed }\end{array}$ & $\begin{array}{l}\text { Total cost } \\
(\text { million }\end{array}$ & $\begin{array}{l}\text { Unit price of } \\
\text { removing } \mathrm{N}\end{array}$ & $\begin{array}{l}\text { Unit price of } \\
\text { (million RMB } / \mathrm{kg})\end{array}$ \\
$\begin{array}{l}\text { removing } \mathrm{P} \\
(\text { million RMB } / \mathrm{kg})\end{array}$ \\
\hline $\begin{array}{c}\text { Traditional } \\
\text { treatment }\end{array}$ & 419.9 & 39.8 & 541.8 & 1.3 & 13.6 \\
$\begin{array}{c}\text { Near-natural } \\
\text { restoration }\end{array}$ & 63.7 & 8.9 & 19.9 & 0.3 & 2.2 \\
\hline
\end{tabular}

\subsubsection{Assessment of Near-Natural River Construction}

The total cost of comprehensive treatment in Liwa River was RMB 5.617 million. The cost of near-natural restoration was RMB 0.199 million, accounting for only $3.5 \%$ of the total cost (Table 17.8).

There were only a few additional expenses for post-restoration management involving macrophyte vegetation harvesting every half year. Other methods typically cost four to six times more than near-natural restoration to remove the same amount of nutrients. This is because near-natural restoration almost exclusively uses solar energy, a very diffuse but sustainable and free energy source (Seidel 1976). Photosynthesis and renewable energy utilization are economical by nature. But it cannot be doubted that it would be a cheaper and more effective treatment for seriously polluted rivers to employ near-natural restoration after traditional environmental engineering techniques that are considered more likely to have an immediate effect.

\subsection{Concluding Remarks}

Near-natural restoration is both a method and a theory. Its meaning surpasses ecology, embracing a philosophy of "harmony between man and nature." Since the era of the Warring States (720-221 вC), the Chinese have investigated the harmonious relationship among Tian (heaven or universe), Di (earth or resource), and Ren (people or society), advocating the union of man and nature. From these investigations, a systematic set of principles for managing the relationship between man and the environment was developed. In particular, principles of holism, symbiosis, circulation and self-reliance were emphasized (Wong and Bradshaw 2008).

In successive phases, appropriate native species were selected, relevant communities from the pioneer to senior phase were built, and each phase of the food cycle was connected, to enable the forest or water system to become a self-maintaining, recycling, living ecosystem. Numerous restoration projects and studies have shown that near-natural restoration could provide ample ecological benefits and enhance environmental quality with minimal human maintenance and a small initial 
investment. Within Shanghai, in addition to the construction of green space in urban areas and greenbelts along the outer circle line, the near-natural forest method could be widely recommended for a number of purposes, including the following: restoring vegetation in garbage disposal fields, creating environmental protection forests in large industrial areas including those occupied by corporations such as the Shanghai Petrochemical Co., Ltd., planting coastal protection forests, creating forest networks within farms, and providing forests for ecological education and research. The method could be regarded as a new means of constructing urban forests, and as central to the construction of urban environments (Da and Song 2008). When planning urban river restoration projects, it is advisable to take advantage of near-natural restoration techniques adapted to local conditions. In most cases, the ecological functioning of river systems can be improved, while simultaneously minimizing the impacts of development and adding genuine social and economic value to the urban environment (Findlay and Taylor 2006).

However, there are still barriers to using near-natural methods in urban areas for restoration purposes, especially the need for management after the restoration, and unfavorable public perceptions. It is recommended that near-natural restoration be pursued through active collaboration with a range of other disciplines in order to improve restoration efforts on multiple fronts.

Open Access This article is distributed under the terms of the Creative Commons Attribution Noncommercial License which permits any noncommercial use, distribution, and reproduction in any medium, provided the original author(s) and source are credited.

\section{References}

Alexander M (1983) Introduction to soil microbiology. Translated by Agricultural Microbiology Research Group, Agricultural College, Guangxi University. Science Press, Beijing

Allen EB, Covington W, Falk DA (1997) Developing the conceptual basis for restoration ecology. Restor Ecol 5:275-276

Cao T, An L, Wang M, Lou YX, Yu YH, Wu JM, Zhu ZR, Qing YK, Glime J (2008) Spatial and temporal changes of heavy metal concentrations in mosses and its indication to the environments in the past 40 years in the city of Shanghai, China. Atmos Environ 42:5390-5402

Chen WM, Zhang QM, Dai SG (2009) The mutual allelopathy of Vallisneria spiralis Linn. and Microcystis aeruginosa. China Environ Sci 29(2):147-151

Ciesla WM, Donaubauer E (1994) Decline and dieback of trees and forests. A global overview. Food and agriculture organization of the United Nations (FAO) Forestry Paper 120. FAO, Rome

Da LJ, Song YC (2008) The construction of near-natural forests in the urban areas of Shanghai. In: Carreiro MM, Song YC; Wu J (eds) Springer Series on environmental management. Springer, New York, pp 420-432

Findlay SJ, Taylor MP (2006) Why rehabilitate urban river systems? Area 38(3):312-325

Gadgil PD, Bain J (1999) Vulnerability of planted forests to biotic and abiotic disturbances. New For 7:227-238

Gao JR (1999) Near natural control: torrent control engineering based on the landscape ecology. J Beijing For Univ 21(1):80-84 (in Chinese) 
Gibson IAS, Jones T (1977) Monoculture as the origin of major forest pests and diseases. In: Cherret JM, Sagar GR (eds) Origins of pest, parasite, disease and weed problems. Blackwell, Oxford, pp 139-161

Graneli W, Solander D (1988) Influence of aquatic macrophytes on phosphorus cycling in lakes. Hydrobiologia 170:245-266

Hobbs RJ (1996) Towards a conceptual framework for restoration ecology. Restor Ecol 4:93-110

Huang JP, Wu CC (2002) Distribution of the microorganism groups in the air of forest area. Sci Silvae Sincae 38(2):173-176

Kan HD, Chen B, Chen CH, Fu Q, Chen M (2004) An evaluation of public health impact of ambient air pollution under various energy scenarios in Shanghai, China. Atmos Environ 38:95-102

Kloor K (2000) Restoring American's forests to their "natural" roots. Science 287:573-575

Kondolf GM (1995) Five elements for effective evaluation of stream restoration. Restor Ecol 3(2):133-136

Li L, Liu NN, Da LJ (2006) Nitrogen and phosphorus accumulation in Iris tectorum and Acorus calamus in eutrophic water. Environ Pollut Control 28(12):901-903 (in Chinese)

Li HJ, Ni LY, Cao T, Zhu LX (2008) Responses of Vallisneria natans to reduced light availability and nutrient enrichment. Acta Hydrobiol Sinica 32(2):225-230 (in Chinese)

Meuleman AFM, Beltman B, Scheffer RA (2004) Water pollution control by aquatic vegetation of treatment wetlands. Wetl Ecol Manag 12:459-471

Miyawaki A (1998) Restoration of urban green environments based on the theories of vegetation ecology. Ecol Eng 11:157-165

Miyawaki A (1999) Restoration of native forests by native trees. Plant Biotechno 16:15-25

Palmer MA, Ambrese RF, Poff NL (1997) Ecological theory and community restoration ecology. Restor Ecol 5:291-300

Ren WW, Zhong Y, Meligrana J, Anderson B, Watt WE, Chen JK, Leung HL (2003) Urbanization, land use, and water quality in Shanghai 1947-1996. Environ Int 29:649-659

Seidel K (1976) Macrophytes and water purification. In: Tourbier J, Pierson RW (eds) Biological control of water pollution. University of Pennsylvania Press, Philadelphia, pp 109-121

Seifert A (1938) Naturnaeherer Wasserbau. Deutsche Wasserwirtschaft 33(12):361-366

Shao HR, He QT (2000) Forest and Air Anion. World For Res 13(5):19-23 (in Chinese)

Starling F, Rocha AJA (1990) Experimental study of the impacts of planktivorous fishes on plankton community and eutrophication of a tropical Brazilian reservoir. Hydrobiologia 200: 581-591

Wang RQ, Fujiwara K, You H (2002) Theory and practices for forest vegetation restoration: native forest with native trees-introduction of the Madawaska's method for reconstruction of "environmental protection forest (ecological method to reforestation)". Acta Phytoecol Sinica 26(suppl):133-139 (in Chinese)

Wang JY, Da LJ, Song K, Li BL (2008) Temporal variations of surface water quality in urban, suburban and rural areas during rapid urbanization in Shanghai, China. Environ Pollut 152: 387-393

Wong MH, Bradshaw AD (2008) Progress in the reclamation of degraded land in China. In: Martin RP, Anthony JD (eds) Handbook of ecological restoration v. 2: Restoration in Practice. Cambridge University Press, Cambridge

$\mathrm{Xu} \mathrm{W,} \mathrm{Wooster} \mathrm{MJ,} \mathrm{Grimmond} \mathrm{CSB} \mathrm{(2008)} \mathrm{Modelling} \mathrm{of} \mathrm{urban} \mathrm{sensible} \mathrm{heat} \mathrm{flux} \mathrm{at} \mathrm{multiple}$ spatial scales: a demonstration using airborne hyperspectral imagery of Shanghai and a temperature-emissivity separation approach. Remote Sens Environ 112:3493-3510

Zhang Y, Zhao YW, Yang ZF, Chen B, Chen GQ (2009) Measurement and evaluation of the metabolic capacity of an urban ecosystem. Commun Nonlinear Sci Numer Simulat 14:1758-1765

Zhang KX, Wang R, Shen CC, Da LJ (2010) Temporal and spatial characteristics of the urban heat island during rapid urbanization in Shanghai, China. Environ Monit Assess 169:101-112

Zhu GP, Wang XR, Wang M, Qi S, Gao JR (2006) Advances on near natural comprehensive control of urban river. Sci Soil Water Conserv 4(1):92-97 (in Chinese) 